\title{
Portfolio formation using the Fama-French five-factor model with modification of a profitability variable: An empirical study on the Indonesian stock exchange
}

\author{
C. Hapsari \& G.H. Wasistha \\ Department of Accounting, Faculty of Economics and Business, Universitas Indonesia, Depok, Indonesia
}

\begin{abstract}
This study aims to analyse portfolio formations using the Fama-French fivefactor model with a modification on the profitability variable. Different portfolio formations are performed for three kinds of profitability variables, which are annual operating profit per total equity (RMW), monthly operating profit per total equity (ROE) and annual operating profit per total assets (ROA). The method used in this study is based on the Fama and French (2015) five-factor model. The result shows that the portfolio formation for the RMW variable has the highest impact on stock return. This result is consistent with the results of Fama and French (2015). This result means that it would be better to use annual operating profit per total equity as the proxy for profitability.
\end{abstract}

\section{INTRODUCTION}

Profitability is one of the main aspects for measuring the effectiveness of company performance. Sharpe (1964) states that, besides profitability, there are other factors that affect the return on an investment, such as market risk, the book-value-to-market-value ratio, or the investment itself. Capital Asset Pricing Model (CAPM) theory explains that the only relevant risk from stock return is the variance from the share itself. This means that an individual risk can be explained by the contributed risk on a portfolio as a whole. However, factors that affect stock return do not simply come from one variable.

Fama and French (1995) introduced the Fama-French three-factor model, which analyses the relationship between stock return and portfolio formation based on the market size and the price-to-book ratio. Continuing on from the 1995 model, Fama and French developed their five-factor model in 2015 (Fama \& French, 2015). The variables that they added were profitability and investment variables. The portfolio formation for the profitability variable used in this model is based on the yearly operating profit divided by total equity (RMW variable).

Other than the yearly operating profit, there are several ways to measure profitability, such as dividing the monthly operating profit by the total equity or the yearly operating profit per total asset. Hou, et al. (2014), on their factor-q model, use the monthly operating profit per total equity as the base for their formation of the profitability variable (ROE variable). On the other hand, Muhammad and Scrimgeour (2014) study stock return using several types of factors, one of which is profitability. Portfolio formation for the profitability variable in Muhammad and Scrimgeour's (2014) research uses the yearly operating profit per total asset (the ROA variable).

The objective of this research is to assess whether the portfolio formation using the RMW variable's influence on stock return is better than using the ROE and the ROA. The previous studies concerning this issue mostly focused on testing the model on their own country or use the same model on the different time period, whereas this research focuses more on the relationship between profitability proxy and portfolio formation. 
This research will use three models, each with a different profitability proxy, i.e. RMW, ROE and ROA. Then each model will be analysed through comparisons (Model I-Model II) and (Model I-Model III).

\section{LITERATURE REVIEW}

If the Fama-French three-factor model is designed only to explain the relationship between return, size and price ratios, the five-factor model tries to explain this relationship by adding two more variables, which are profitability and investment. The Fama and French (2015) five-factor model shows that a high return could be gained from the stock of a company that is small in size, by having a high price-to-book capitalisation ratio, being profitable and being conventional in their investment strategy.

There are five variables that are used in this model. The first variable is SMB (Small Minus Big). Positive SMB means that a company with a small size will give a better return compared to a company with a bigger size, and vice versa. The next variable is HML (High Minus Low). Positive HML means that a stock with a lower book-to-price ratio will give a better return compared to a stock with a bigger book-to-price ratio, and vice versa. The third variable is market premium or Rm-Rf. Market premium is an additional return received by investors because they invest in stocks and not in risk-free assets, such as short-term treasury bills. The fourth variable is CMA (Conservative Minus Aggressive). Positive CMA means that the stock of a company that is more aggressive in undertaking investments will get less return compared to the stock of a more conservative company. The reason why the stocks of conservative companies will give a better return is because these companies only make investments when they actually have the funds to do so, and they choose their options carefully in order not to make a mistake that will result in a less stable financial condition (Rankine, 2001). The last variable is RMW (Robust Minus Weak). Positive RMW means that the stock of a company with a higher profitability will give greater returns compared to the stock of a company with lower profitability (Fama \& French, 2015).

Fama and French (2015) also find that when they use the five-factor model, size is not a factor that influences stock return. The Fama-French five-factor model shows that a high return can be obtained from the stock of a company that has small capital, a high bookto-market capitalisation ratio, is profitable and is conventional in developing its investment strategy (Fama \& French, 2015).

\section{HYPOTHESIS BUILDING}

Profitability is an indicator of company's performance in carrying out its activities in order to achieve the company's objectives, namely to optimise profits for stockholders. High profitability reflects the company's financial situation, in which the company has good financial conditions that allow them to develop their business when needed.

$R M W$ variable is the new profitability variable that was introduced by Fama and French in 2015 in their new research model, the Fama-French Five-Factor Model (FF5F Model). $R M W$ variable is obtained from the difference between the stock return for a portfolio with a high yearly operating profit per total equity and the stock return for a portfolio with a low yearly operating profit per total equity. In their research, Fama and French found a positive relationship between a $R M W$ variable and return. This result means that a company with higher profitability will give a better return on their stock.

Hou et al. (2014) use the $R O E$ variable on their model to identify the relationship between certain factors and stock return. $R O E$ variable is computed from the difference between the stock return of a portfolio with a higher ratio of the monthly operating profit per total equity and the stock return of a portfolio with a lower ratio of the monthly operating profit per total equity. They found that the portfolio formation for the $R O E$ variable that is calculated 
from the monthly operating profit per total equity will give a better stock return based on neoclassical economic theory.

$H 1$ : Portfolio formation using the $R M W$ variable is better than portfolio formation using the $R O E$ variable as a profitability proxy to stock return.

Muhammad and Scrimgeour (2014) used the $R O A$ variable in their research to analyse the effect of the financial ratio on stock return in the Australian Stock Exchange. In their research, the $R O A$ variable is defined as the difference between stock return on a portfolio with a high ratio of the yearly operating profit per total asset and stock return on a portfolio with a low ratio of the yearly operating profit per total asset.

$H 2$ : Portfolio formation for the $R M W$ variable is better than portfolio formation for the $R O A$ variable as a profitability proxy to stock return.

\section{EMPIRICAL MODEL}

This research uses the model based on the FF5F Model (2015):

$$
R_{i t}-R_{r t}=a_{i}+b_{i}\left(R_{M t}-R_{r t}\right)+s_{i} S M B_{t}+h_{i} H M L_{t}+r_{i} R M W_{t}+c_{i} C M A_{t}+e_{i t}
$$

where:

$R_{i t}=$ Stock return for portfolio $i$ at period $t$.

$R_{F t}=$ Risk-free return at period $t$.

$R_{M t}=$ Market average portfolio return at period $t$.

$S M B_{t}=$ Portfolio return that is diversified on small size stock minus portfolio return that is diversified on a big size stock at period $t$.

$H M L_{t}=$ Portfolio return that is diversified on a company with a big price-to-book ratio minus portfolio returnthat is diversified on a company with a small price-to-book ratio at period $t$.

$R M W_{t}=$ The difference between portfolio return that is diversified on stock and high profitability and low profitability at period $t$.

$C M A_{t}=$ The difference between portfolio return that is diversified on stock of a conservative company and an aggressive company in investment strategy at period $t$.

There are two other models that have the same variables as the model above, except for the profitability variables. The other two models replace the profitability variable with a different type of profitability variable, which are the ROE variable and the ROA variable.

The samples for this research are the listed companies whose stocks are actively traded in the Indonesian Stock Exchange, excluding financial companies, from January 2012 to December 2014. The total number of companies that are used in this research is 316 .

The steps of the portfolio formation for the three models are as follows:

1. Data of stock return portfolio from 316 companies are arranged based on capitalisation value.

2. Stock portfolio is divided into two sizes based on capitalisation: small and big.

3. The small size stock portfolio will be rearranged later into three parts based on the BE/ ME ratio, 30\% lowest, $40 \%$ medium and 30\% highest. The big size stock portfolio will also be arranged into three parts based on the BE/ME ratio, 30\% lowest, $40 \%$ medium and $30 \%$ highest.

4. The small size stock portfolio will be arranged based on market premium, investment and profitability into three parts, $30 \%$ lowest, $40 \%$ medium and $30 \%$ highest. The same treatment also applies to the big size stock portfolio.

5. Profitability factor will be arranged based on three variable types used in this research, which are $R M W, R O E$, and $R O A$.

To determine which portfolio formation is better as the profitability proxy, the significance level will be used as the basis. Significance level is a way to determine whether the dependent 
variable has any relation to the independent variable. Thus, a smaller significant level means that the dependent level has a better relation to the independent level.

\section{RESULTS AND ANALYSIS}

A normality test, multicollinearity test and heteroscedasticity test are performed, and no irregularity is found. The results for multiple regressions are as shown in Table 1, Table 2 and Table 3:

The results of the multiple regression show a significant value for the RMW variable. Positive RMW means that the stock of a company with higher profitability will give more return compared to the stock of a company with lower profitability. One of the reasons why RMW has positive effects on stock return is because the stock of a company with lower profitability

Table 1. Result of regression model (with the $R M W$ variable).

\begin{tabular}{|c|c|c|c|c|c|}
\hline \multirow[b]{2}{*}{ Model } & \multicolumn{2}{|c|}{$\begin{array}{l}\text { Unstandardised } \\
\text { coefficients }\end{array}$} & \multirow{2}{*}{$\begin{array}{l}\begin{array}{l}\text { Standardised } \\
\text { coefficients }\end{array} \\
\text { Beta }\end{array}$} & \multirow[b]{2}{*}{$T$} & \multirow{2}{*}{$\begin{array}{l}\text { Prob. } \\
\text { Val }\end{array}$} \\
\hline & $B$ & Std. Error & & & \\
\hline (Constant) & -0.027 & 0.007 & & -4.020 & 0.000 \\
\hline SMB & 0.004 & 0.002 & 0.238 & 2.061 & 0.048 \\
\hline CMA & 0.004 & 0.002 & 0.328 & 2.415 & 0.022 \\
\hline RMW & 0.006 & 0.001 & 0.532 & 4.326 & 0.000 \\
\hline HML & 0.001 & 0.002 & 0.053 & 0.358 & 0.723 \\
\hline $\mathrm{RmRf}$ & 0.520 & 0.106 & 0.545 & 4.897 & 0.000 \\
\hline
\end{tabular}

Table 2. Result of regression model (with the $R O E$ variable).

\begin{tabular}{|c|c|c|c|c|c|}
\hline \multirow[b]{2}{*}{ Model } & \multicolumn{2}{|c|}{$\begin{array}{l}\text { Unstandardised } \\
\text { coefficients }\end{array}$} & \multirow{2}{*}{$\begin{array}{l}\begin{array}{l}\text { Standardised } \\
\text { coefficients }\end{array} \\
\text { Beta }\end{array}$} & \multirow[b]{2}{*}{$T$} & \multirow{2}{*}{$\begin{array}{l}\text { Prob. } \\
\text { Val }\end{array}$} \\
\hline & $B$ & Std. Error & & & \\
\hline (Constant) & -0.018 & 0.010 & & -2.450 & 0.020 \\
\hline SMB & 0.005 & 0.000 & 0.260 & 1.930 & 0.060 \\
\hline CMA & 0.002 & 0.000 & 0.140 & 0.930 & 0.360 \\
\hline ROE & 0.004 & 0.000 & 0.280 & 2.330 & 0.030 \\
\hline HML & 0.000 & 0.000 & -0.030 & -0.150 & 0.880 \\
\hline $\mathrm{RmRf}$ & 0.641 & 0.120 & 0.670 & 5.470 & 0.000 \\
\hline
\end{tabular}

Table 3. Result of regression model (with the $R O A$ variable).

\begin{tabular}{|c|c|c|c|c|c|}
\hline \multirow[b]{2}{*}{ Model } & \multicolumn{2}{|c|}{$\begin{array}{l}\text { Unstandardised } \\
\text { coefficients }\end{array}$} & \multirow{2}{*}{$\begin{array}{l}\text { Standardised } \\
\text { coefficients }\end{array}$} & \multirow[b]{2}{*}{$T$} & \multirow{2}{*}{$\begin{array}{l}\text { Prob. } \\
\text { Val }\end{array}$} \\
\hline & $B$ & Std. Error & & & \\
\hline (Constant) & -0.027 & 0.008 & & -3.546 & 0.001 \\
\hline SMB & 0.004 & 0.002 & 0.229 & 1.864 & 0.072 \\
\hline CMA & 0.005 & 0.002 & 0.443 & 2.767 & 0.010 \\
\hline HML & 0.002 & 0.002 & 0.125 & 0.754 & 0.457 \\
\hline $\mathrm{RmRf}$ & 0.522 & 0.116 & 0.546 & 4.482 & 0.000 \\
\hline ROA & 0.007 & 0.002 & 0.599 & 3.558 & 0.001 \\
\hline
\end{tabular}


is more vulnerable to macroeconomic and industry conditions (Hao et al., 2011). It will be difficult for companies that have low profitability to compete when the general economic situation is not good. These companies usually lack the resources, including the adequacy of funds, which makes it harder for them to compete with companies with a high profitability.

Companies with small RMW mean that companies with same range of book value are relatively less profitable than companies with a high RMW. This also means that they are less than optimal in managing equity to achieve the goals of the company. Equity here includes common shares and dividends. As a result, the company's profit achieved during this period will also be low, and this will have an impact on the amount of dividends received by the stockholders. Furthermore, this condition will be reflected in the company's stock price and ultimately in its stock return. Equally, companies with a high RMW will give a higher return. These companies can use the funds from the undistributed profit to stockholders (retained earnings) to increase the company's performance, so it can reach the optimum capacity. The result of this research is in accordance with the findings proposed by Fama and French (2015).

ROE also shows a significant value to stock return. It means that the portfolio formation for ROE has an influence on stock return, even if the significance level is lower than that of the RMW variable. This result is consistent with the result of Hou et al. (2014).

Hence, RMW gives a better explanation for the relationship between profitability and stock return. The difference between these two variables is the period used on these variables, which are monthly and yearly. According to Fama and French (2015), the Fama-French five-factor model is formed or derived from the model formulation of the Dividend Discount Model (DDM). Thus, this model has already included the information on dividends. This means that, in addition to capital gain, dividend is also a factor that drives the investors in Indonesia to invest in stocks. Indonesian investors are attentive to a company's annual financial statement data in deciding whether or not to buy a company's stock.

The implication of this result is that investors who choose to focus on stocks from companies with low profitability will get a smaller return than those who buy stocks from companies with high profitability.

The multiple regressions also show a significant result for the ROA variable. The ROA variable is the variable that is used in many studies. One of these studies is done by Muhammad and Scrimgeour (2014). The ROA variable in this research is acquired based on portfolio formation of the yearly operating profit divided by total assets. This result shows a company's profitability on an accounting term divided by total assets also related to return. A positive ROA coefficient also means that a higher value of ROA will give higher returns in the future. This result is in accordance with Muhammad and Scrimgeour's (2014) result, which also finds the relationship between the ROA variable and return.

The ROA variable tries to find out the effectiveness of the company's management in managing its asset in order to achieve their planned operating profit for the year. A high value ROA means that the company gets high operating profit for every asset that is used.

The relationship between ROA and stock returns is that a higher ROA will give a better return for investors who invest in those companies. Companies with a high ROA will have advantages in optimising the use of their assets to increase their operating profit. Effective performance will be reflected in the company's annual financial report, so that ultimately this information will be reflected in the company's stock price.

The difference between the RMW variable and the ROA variable in this research is the denominator, which is total equity for the RMW and total asset for the ROA.

Although the ROA variable has a positive effect on the return, RMW still has a better significance level. Also, the RMW variable is a better variable in explaining the dependent variable, so it can be said that generally RMW is a better variable for explaining the relationship between profitability and return. RMW links with the denominator of each variable, which is total equity and total assets. It can also be linked with DuPont analysis, which states that $\mathrm{ROE}$ is ROA that has a company's leverage information. Leverage information is a factor that needs to be considered in order to understand a company's profitability. Thus, the RMW variable has more influence on returns compared to the ROA variable. 
The implication of this research is that investors who choose to invest based on the yearly operating profit divided by total equity will get greater returns compared to those who choose to invest based on the yearly operating profit divided by total assets.

\section{CONCLUSION}

This research concludes that all of the three profitability variables used in this research model have a positive effect on stock return. That means that the portfolio formation for RMW, ROE and ROA has a positive coefficient, as can be seen in the multiple regression results.

From the models used in this research, the RMW variable is better than the ROE variable in representing profitability. This is related to the Fama and French (2015) FF5F Model, which is based on the Dividend Discount Model. Fama and French (2015) use the data of the yearly operating profit because the data already includes dividend information that is not included in the monthly operating profit data.

This research also concludes that the RMW variable is better than the ROE variable in representing profitability. This is related to the leverage factor. The ratio that is used in portfolio formation for the RMW variable already contains the leverage factor, which is not applicable in ROA, so the RMW variable has a greater effect on stock return.

To sum up the results of this research, the portfolio formation for the profitability factor based on the yearly operating profit per total equity will give a higher return compared with the monthly operating profit per total equity or yearly operating profit per total asset.

In addition to the profitability factor, other variables that have an effect on stock return, based on the results of this research, are market premium, portfolio formation for the SMB variable, and the CMA variable. This research also finds that market premium, portfolio formation for SMB and CMA variables have a positive effect on stock return.

For further advancement on this topic, more types of ratios, such as EPS (Earning per Share) or DPR (Dividend Payout Ratio), can be used as a base for portfolio formation.

\section{REFERENCES}

Fama, E.F. \& French, K.R. (1995). Size and book-to-market factors in earnings and returns. The Journal of Finance, 50(1), 131-55. doi:10.1111/j.1540-6261.1995.tb05169.x.

Fama, E.F. \& French, K.R. (2015). A five-factor asset pricing model. Journal of Financial Economics, 116(1), 1-22. doi:10.1016/j.jfineco.2014.10.010.

Hao, S., Jin, Q. \& Zhang, G. (2011). Relative firm profitability and stock return sensitivity to industrylevel news. Accounting Review, 86(4), 1321-47. doi:10.2308/accr-10042.

Hou, K., Chen, X. \& Zhang, L. (2014). A comparison of new factor models. NBER Working Paper 20682, National Bureau of Economic Research, Cambridge, MA.

Muhammad, N. \& Scrimgeour, F. (2014). Stock returns and fundamentals in the Australian market. Asian Journal of Finance \& Accounting, 6(1), 271-90. doi:10.5296/ajfa.v6i1.5486.

Rankine, Denzil. Why Acquisitions Fail: Practical Advice for Making Acquisitions Succeed. London: Pearson Education, 2001.

Sharpe, W.F. (1964). Capital asset prices: A theory of market equilibrium under conditions of risk. The Journal of Finance, 19(3), 425-42. doi:10.1111/j.1540-6261.1964.tb02865. 